\title{
Glaciers Dynamics Over the Last One Century in the Kodori River Basin, Caucasus Mountains, Georgia, Abkhazeti
}

\author{
Levan G. Tielidze ${ }^{1}$, Lela Gadrani ${ }^{1}$, Mariam Tsitsagi ${ }^{1}$, Nino Chikhradze ${ }^{1,2}$ \\ ${ }^{1}$ Vakhushti Bagrationi Institute of Geography, Ivane Javakhishvili Tbilisi State University, Tbilisi, Georgia \\ ${ }^{2}$ Ilia State University, Tbilisi, Georgia
}

Email address:

levan.tielidze@tsu.ge (L. G. Tielidze), levan_tielidze@yahoo.com (L. G. Tielidze)

\section{To cite this article:}

Levan G. Tielidze, Lela Gadrani, Mariam Tsitsagi, Nino Chikhradze. Glaciers Dynamics Over the last One Century in the Kodori River Basin, Caucasus Mountains, Georgia, Abkhazeti. American Journal of Environmental Protection. Special Issue: Applied Ecology: Problems, Innovations. Vol. 4, No. 3-1, 2015, pp. 22-28. doi: 10.11648/j.ajep.s.2015040301.14

\begin{abstract}
This paper considers the last one century's dynamics of the glaciers in the Kodori River basin, which is located on the southern slope of the Greater Caucasus in Georgia. The latest statistical information is also given about the glaciers located in the individual river basins; Their morphological types, exposition and the dynamics are considered according to the individual years. In our research, we used the Catalogue of the glaciers of Georgia compiled by K. Podozerskiy in 1911. We also used the military topographic maps with the scale of 1:25 000 and 1:50 000 drawn up in 1960, where there are mapped in detail the glaciers and the ends of their ice tongues on the southern slope of Greater Caucasus of those times. We also used the remote sensing method, which is the best modern way for the study of the dynamics of glaciers and this method is remarkable by a quick obtaining of results. The spectral images of the Landsat L5/TM and ASTER L1/A are the necessary materials for our study. As a result of the use of this method, we have identified the dynamics of the glaciers in the Kodori River basin.
\end{abstract}

Keywords: Glaciers Dynamics, Glaciers of Georgia Caucaus Mountains, Remote Sensing, Climate Change in Georgia, Glaciers of Abkhazeti

\section{Introduction}

It is known that the glaciers are the most important resource of the world's fresh water, that's why they always play an important role in the evolution of natural conditions and therefore, in the evolution of the biosphere. Melting of glaciers due to modern climate change is observed in all mountainous regions of the world.

Mountain glaciers play an important role in the regional hydrological cycle by modulating the storage and release of freshwater so, as they retreat, the availability of runoff for irrigation and hydro-power generation is altered [1].

In Georgia research of the glaciers on the southern slope of the Greater Caucasus has a long time history. The first scientific reports are given by a great Georgian scientist Vakhushti Bagrationi in the beginning of the 18th century as yet [2].

The compilation of the first reliable map of the Greater Caucasus at a scale of 1:420,000 and depicting the largest glaciers was completed by 1862 . Topographic surveys of the Great Caucasus at a scale of 1:42,000 were accomplished 30 years later. Having analyzed these maps, K.I. Podozerskiy in 1911 published the first catalogue of the Great Caucasus glaciers, compiling data on the lengths and areas of all of the glaciers [3].

Observation on the glaciers of the Western, Central and Eastern Caucasus is continuous since $30 \mathrm{~s}$ of the $20^{\text {th }}$ century to the present day. The scientists from the Vakhushi Bagrationi Institute of Geography conduct the permanent monitoring of the glaciers of Svaneti, Abkhazeti (by means of modern space images) Racha and Khevi Caucasus.

In Georgia contemporary glaciers are mainly concentrated in the Enguri, Rioni, Kodori and Tergi River basins. Main centers of the glaciation are related to the higher elevated Greater Caucasus and Kazbegi massif. Also, there are the individual centers in the branch ranges of the Greater Caucasus. Nowadays there are 637 glaciers in Georgia with the total area of $355.8 \mathrm{~km}^{2}[2,4]$.

\section{Study Area}

Kodori River basin is located on the southern slope of the Western Caucasus (Fig.1). Kodori gorge is divided into 
several sections from the headwaters to the confluence due to the morphological, lithological and tectonic features.

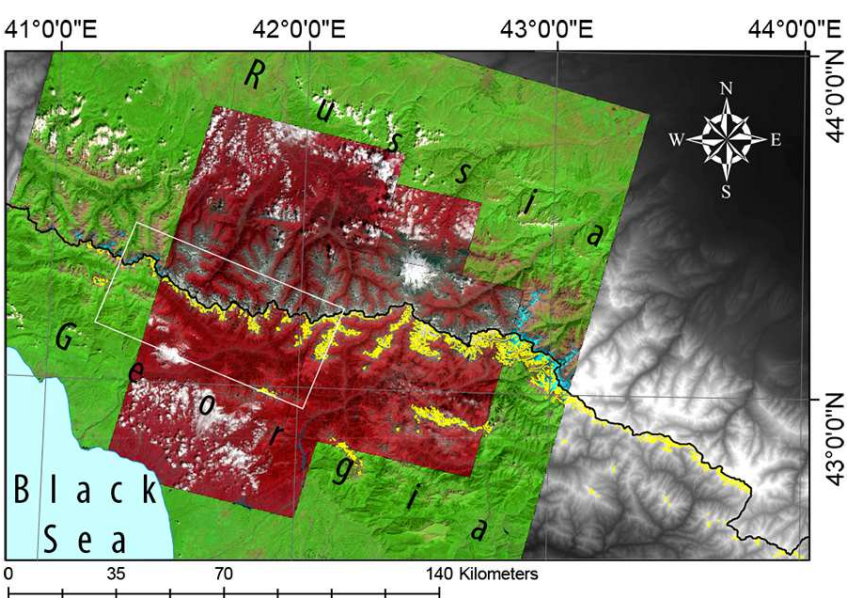

Fig. 1. Location of the Kodori River Basin, Landsat and ASTER Imagery

Gorges of the Kodori River tributaries (Ptishi, Khetskvara, Klich, Ghvandra and Sakeni) is located on the southern slope of the Greater Caucasus are of meridional and submeridional directions. Morphologically they are trough valleys and are deeply sat in the relief and are slightly modified by the erosion processes. Glacial deposits-moraines are spread on the bases and slopes of the valleys. Erosion forms are poorly represented (debris cones). Numerous snow avalanches are involved in the modeling of the valleys [5].

Study of the glaciers of the Kodori River basin began in the last century as yet. Famous researchers of the Greater Caucasus gave us information about glaciers: G. Radde (1873), N. Bush (1905), K. Podozerskiy (1902, 1911), P. Ivankov (1959), D. Tabidze (1965, 1966, and 1975) and R. Gobejishvili (1989).

Southern slope of the Western Caucasus from Marukhi to Dalari Passes presents the main center of glaciation in the Kodori River basin. High peaks such as Marukhi, Ertsakho, Sopruju, Dombai Ulgeni, Khakeli and Ghvandra are located in this section. Their height is over $3800-4000 \mathrm{~m}$. Isolated glaciation enters are presented in the Kodori, Chkhalta (Abkhazeti), Khutia and Klich ranges. Especially should be noted the western and south-western slopes of the Kharikhra range, which is a main glaciation center in the Sakeni River basin. Peaks higher than $3700 \mathrm{~m}$ are located in this range, they are: Kharikhra, Maguashikhra and Okrilatavi.

\section{Data and Methods}

In this research we used the catalogue and maps of glaciers compiled by K. Podozerskiy in 1911. Although in the mentioned maps in some cases there are mistakes made in visualization of areas and number of glaciers, but this is the most reliable and adequate source to get the information about the glaciers conditions of those times.

Also we used the military topographic maps of $1: 25,000$ and 1:50,000 scales created in 1960, where the glaciers, the ends of their ice tongues and the firn line of the southern slope of the Greater Caucasus of those times are depicted in detail. These maps are in the Pulkovo-1942 projection. We used standard transformation parameters to re-project the map in Universal Transverse Mercator (UTM), zone 38-North on the WGS84 ellipsoid, to facilitate comparison with modern datasets.

We used the Remote Sensing research method as well. Remote sensing is an deft tool for increasing the number of monitored glaciers on a global scale, especially in remote or politically sensitive areas. It has the added advantage of allowing a single user to determine changes in glacier surface characteristics over very large areas (thousands of $\mathrm{km}^{2}$ ), and is extremely rapid when compared to field investigation $[6,7,8$, 9]. Landsat L5/TM (Thematic Mapper), with $30 \mathrm{~m}$ horizontal resolution available since 1982 and 1999 respectively, and Advanced Spaceborne Thermal Emission and Reflection Radiometer (ASTER) imagery with $15 \mathrm{~m}$ resolution available since 2000 [10]. Together with historical topographical maps, this imagery enabled assessments at time steps of 50-55 years during which the magnitude of glacier change significantly exceeded measurement errors.

Therefore, except the map of 1911 by Podozerskiy and topographical maps of 1960, the spectral image Landsat L5 TM (Thematic Mapper) and ASTER L1/A taken in August of 2014 is a necessary material for investigation. The mentioned case corresponds to the clear weather conditions, when the impact of snow cover on glaciers and the absence of clouds facilitate to perfect visibility of objects on the Earth's surface. Then we used the Composite Bands function with the help of ArcGis program and put the images in the sequence of 7-4-2 (for Landsat) and 3N-2-1 (for ASTER). As a result of the application of the mentioned method we identified the variability in the area of the glaciers of the Kodori River Basin in 1911-1960-2014, as well as the altitudinal variability in the glaciers length and ice tongues according to the mentioned years.

\section{Results and Discussion}

According to the data of K. Podozerskiy, at the end of the 19th century there were 118 glaciers in the Kodori River basin with the area of $73.2 \mathrm{~km}^{2}$ [11]. according to the data of D. Tabidze (according to the 1946 aero images) - there were 141 glaciers with the area of $60.0 \mathrm{~km}^{2}$ [12]. And by the data of R. Gobejishvili (based on the topographic maps of 1960) - there were 160 glaciers with the area of $64.5 \mathrm{~km}^{2}$ [13]. By the data of 2014 there are 145 glaciers in the basin with a total area of 40.1 $\mathrm{km}^{2}$ [2]. The glaciers are unevenly distributed in the Kodori River basin, not only according to the orographical units, but also according to the individual tributary river basins.

Here dominate small glaciers by a number. The glaciers are distributed according to the tributary river basins as follows (Fig. 2).

The glaciers of all morphological types are distributed in the Kodori River basin except of the compound-valley type. Morphological and morphometric characteristics of the relief and climatic conditions are favorable for the existence of 
multiple cirque type glaciers. Cirque type glaciers occupy the first place according to the number and area. $66.2 \%$ of the total number of glaciers of the Kodori River basin is the share of them, as well as $48.1 \%$ of the total area of the glaciers of the Kodori River basin is a share of the cirque type glaciers (Fig.
3).

According to the area, the second place occupy the glaciers of cirque-valley type and according to the number, the second place occupy the cirque-hanging glaciers.

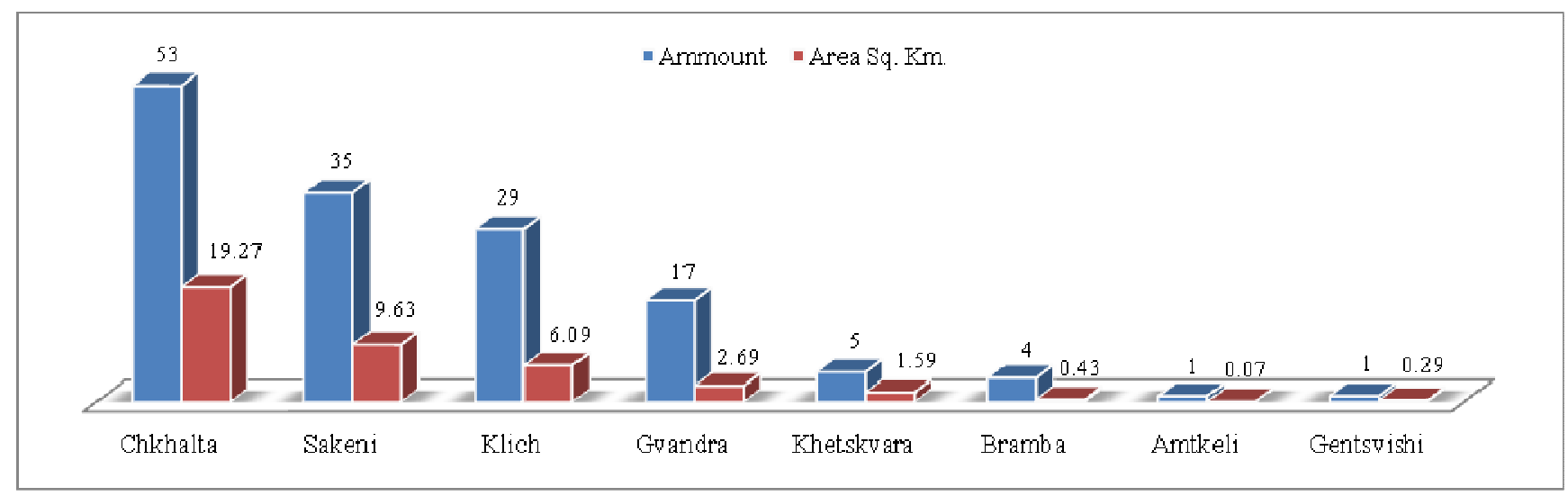

Fig. 2. Distribution of the Glaciers of the Kodori River Basin according to the Tributary River Basin

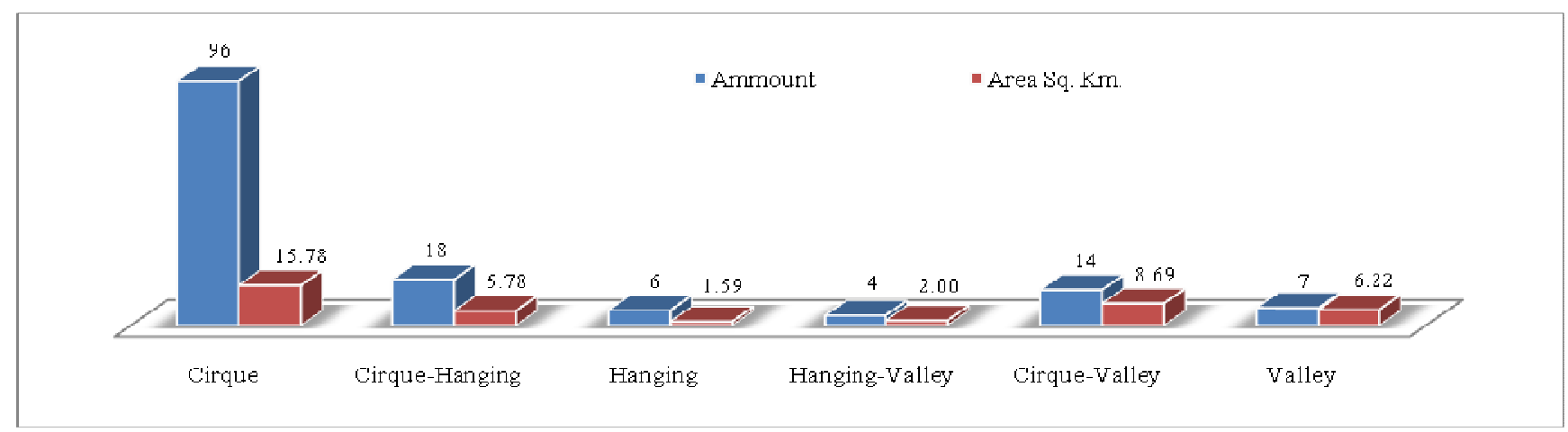

Fig. 3. Distribution of the Glaciers in the Kodori River Basin according to the Morphological Types

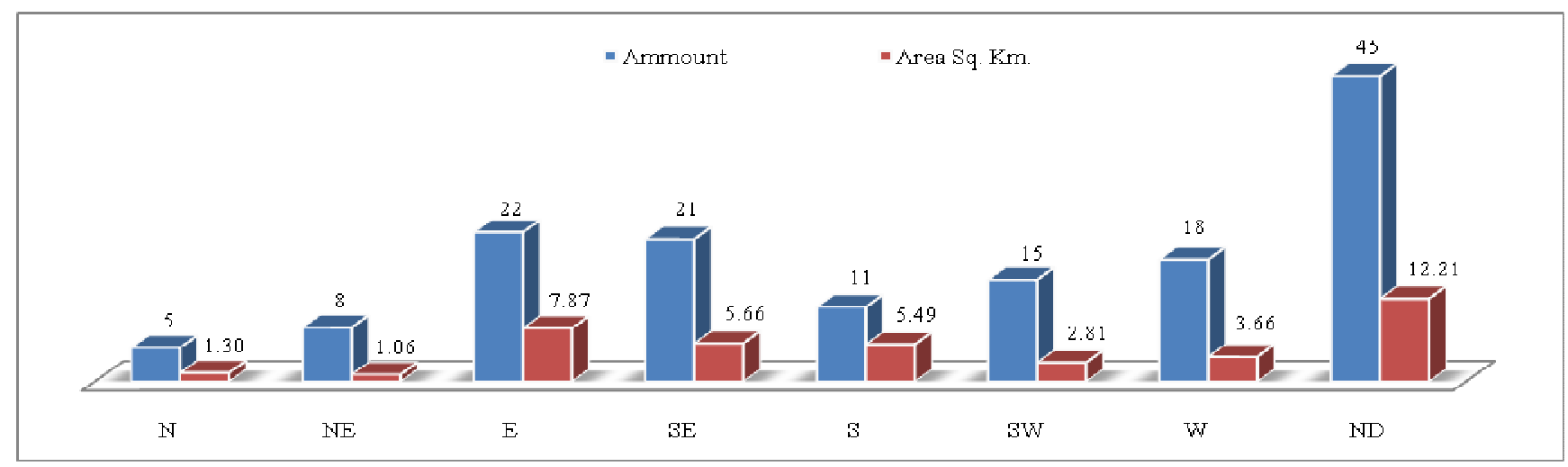

Fig. 4. Distribution of the Glaciers in the Kodori River Basin according to the Exposition

There are the glaciers of all expositions in the Kodori River basin (Fig. 4). By number exceed the glaciers of north-western exposition $-31.0 \%$, then comes the glaciers of the eastern exposition $-15.2 \%$ and south-eastern expositions $-14.5 \%$. According to the occupied area, there is a same sequence: north-western exposition $-30.5 \%$, eastern exposition $-19.6 \%$ and south-eastern $-14.1 \%$.

Kodori River basin is located on the southern slope of the Greater Caucasus and the exposition should be mainly of southern direction, but the conducted study shows that the glaciers of northern exposition dominate, both in number and area. Predominant distribution of the glaciers of northern exposition can be explained by the sublatitudinal or latitudinal direction of branch ranges.

As it was already mentioned, the glaciers of the Kodori River basin are not equally distributed, not only according to the orographical units, but also according to the individual river basins; therefore, to have a clearer idea on the 
contemporary glaciers of the Kodori River and its tributary river basins and their variability in time and space, it is necessary to consider these basins separately.

Chkhalta River basin. $36.6 \%$ of the amount and $48.1 \%$ of the area of the glaciers of the Kodori River basin are the shares of the Chkhalta River Basin. Similarly as in the entire Kodori basin, here also, observed reduction the total amount and area of glaciers (Fig. 5).

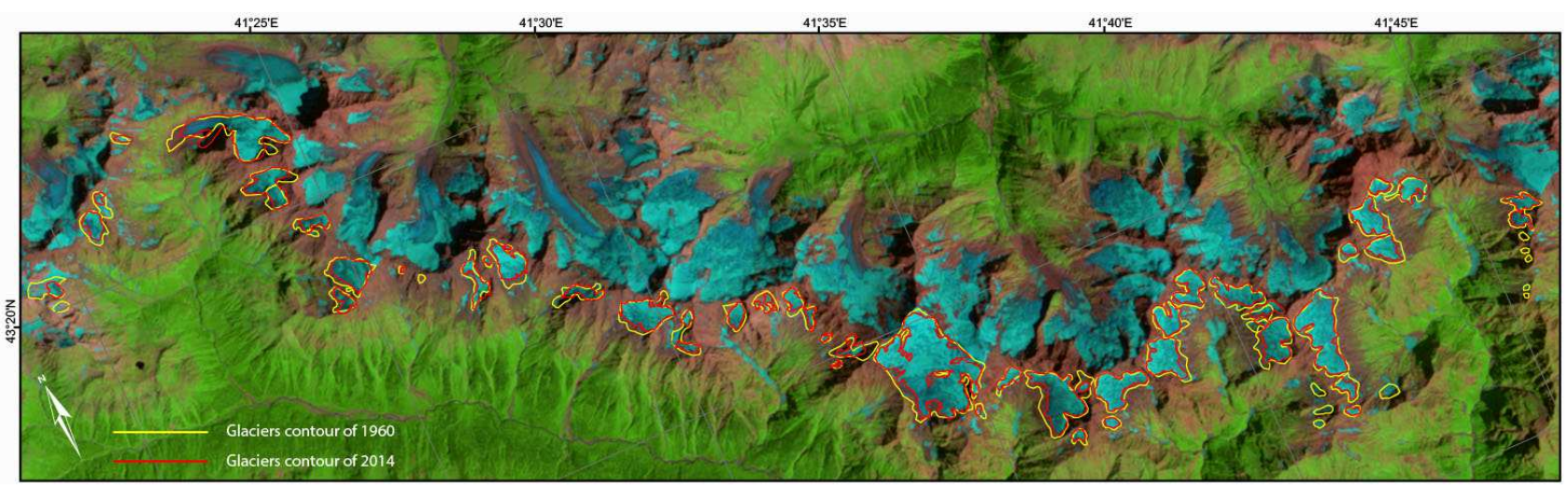

Fig. 5. Glaciers Retreat in the Chkhalta River Basin in 1960-2014 (Landsat L5/TM)

The glaciers are distributed unequally by the morphological types and exposition. Two centers of the glaciation can be distinguished in the Chkhalta River basin.

A separate description of the Marukhi River basin has its preconditions: 1 . it is a completely separate center in terms of the contemporary glaciation. 2. According to the old glaciations this basin was independent as well.

By Podozerskiy (1911) 12 glaciers were in the Marukhi River basin, and their area was $6.4 \mathrm{~km}^{2}$. By the data of 1960 year 10 glaciers with the area of $4.8 \mathrm{~km}^{2}$ were presented in this basin. 9 glaciers with the total area of $3.9 \mathrm{~km}^{2}$ are by 2014 data.

Marukhi glacier is the largest one in this basin, which belongs to the type of valley glacier. Its area is $1.7 \mathrm{~km}^{2}$, and the length is $\sim 4.1 \mathrm{~km}$. Marukhi has a clearly defined ice tongue and $\sim 300 \mathrm{~m}$ high icefall. The ice tongue is about $\sim 1.5 \mathrm{~km}$ long, which is weakly fractured and characterized by a slight inclination. The central part of the tongue is clean, only its last section is covered with loose material. The surface of the ice tongue is rugged by melting waters due to its weak fracturing and slight inclination. Water-raised grooves are quite large ( $\sim 2-5 \mathrm{~cm}$ wide) and they can be found only on the pure glacier surface. In front of the ice tongue at a distance of $\sim 800-900 \mathrm{~m}$ long, in the valley (the glacier trough) there are moraine hillocks of different sizes, which allows us to rebuild the location of the glacier during the Fernau stage and discuss its dynamics for the last $\sim 200$ years. It is true that Marukhi glacier has no lateral stade moraines, but the trace of the stade glacier is distinguished on the both slopes of the valley by a sharp line (according to the moraine material spread on the slope, vegetation cover, slope color tone and other morphological parameters). The last stade and microstade moraines are well-expressed in the valley. The last Fernau stade moraine covers the top of the ledge and is presented by $\sim 10-15 \mathrm{~m}$ thick loose material. Thickness of the microstade moraines is $\sim 1.3 \mathrm{~m}$. There is a $\sim 150-200 \mathrm{~m}$ long straight surface between the microstade moraines, which is built by the fluvioglacial deposits. As a whole, there are three microstade moraines in the valley with two rows per each.

In August of the years of 1975-1982 the phototheodolite survey of the Marukhi ice tongue was conducted [2]. The plan of 1:5000 scale was compiled. The mentioned map clearly explaines the morphometric and morpographic peculiarities of the ice tongue and the area in front of it.

The rest of the glaciers of Marukhi River Basin is the glaciers of small cirque and cirque-hanging types. They are mainly located in the headwaters of the rivers of Buloni and Chvakhra. These basins fed the large Marukhi glacier during the Wurm glaciation together with the Marukhi River basin.

The left section of the Chkhalta River gorge from the Mount Ertsakho to Mount Ptishi covers the southern slope of the Great Caucasus. The peaks create good conditions for existence of glaciers. By 1960 data there were 32 glaciers with the area of $15.6 \mathrm{~km}^{2}$. By 2014 data there are 25 glaciers with the total area of $8.1 \mathrm{~km}^{2}$. The comparison between the mentioned data well depicts the degradation of glaciers in recent decades.

In the given section the biggest glacier is the Southern Sopruju (Fig. 6). The glacier has an extensive firn field, and the ice tongue is characterized by small parameters and it is hanging over the ledge. The glacier is slightly fractured, let alone the last section of the ice tongue. Due to morphological conditions of the area the glacier suffers the lack of moraine material (both the bed moraine and surface moraine material). The glacier exarates the bedrocks. The Sopruju glacier is the largest in size in the whole Kodori River basin; Its area is 3.7 $\mathrm{km}^{2}$.

Atsiash-Atsgara River headwater is distinguished by the independent center of glaciation, which morphologically represents an old cirque. By 2014 data here are the eight glaciers. All eight glaciers are of cirque-hanging type. Their total area is $3.8 \mathrm{~km}^{2}$

Ptishi River is a left tributary of the Chkhalta River. The morphology and morphometric features of the relief of its headwaters create better conditions for the existence of glaciers. By the data of 1960 there were 12 glaciers with the 
area of $4.0 \mathrm{~km}^{2}$, and by the data of 2014 there are 7 glaciers with the total area of $1.8 \mathrm{~km}^{2}$.

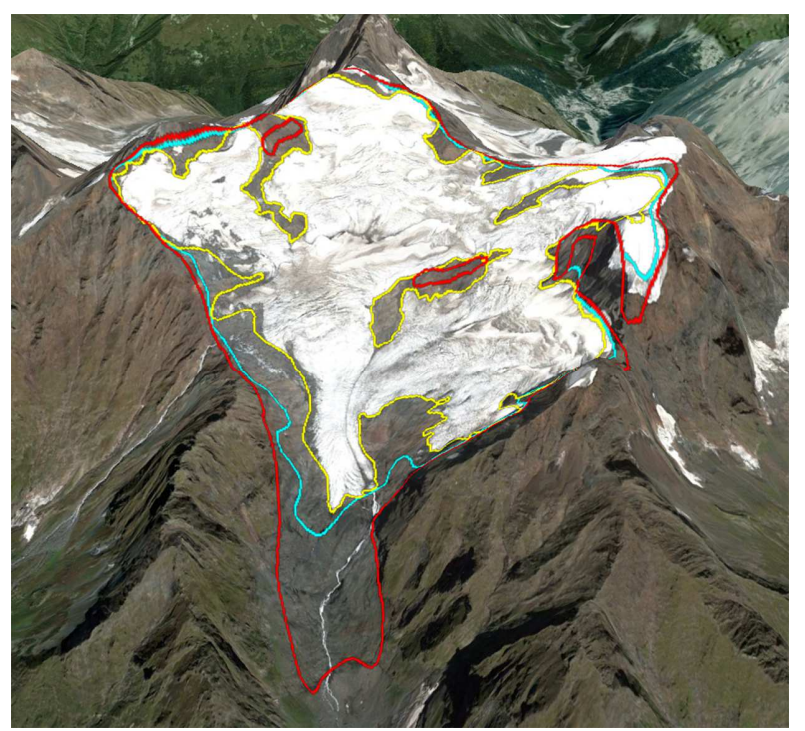

Fig. 6. Sopruju Glacier Retreat in 1911-1960-2014 (Googla Earth Image)

The glaciers in the Khetskvara River basin are developed on the western slope of the Khutia range. By K. Podozerskiy (1911) there were 6 glaciers in this basin with the area of 2.8 $\mathrm{km}^{2}$. By 1960 data the number of the glaciers and their area remained unchanged. By 2014 data there are 5 glaciers with the total area of $1.6 \mathrm{~km}^{2}$. Four glaciers are of cirque type morphologically, and one - is of hanging type.

Due to the fact that the glaciers are distributed in the western slope of the Khutia range, their exposition is northwestern and western.

According to the topographical maps of 1960 there were two small cirque type glaciers of southern exposition in the Gentsvishi River basin. There is no information on them in the work of K. Podozerskiy. By 2014 data there is a small cirque type glacier of south-eastern exposition.

Klich River basin is the only gorge in the Kodori River basin, which maintains the shape of the trough valley along the whole distance. Contemporary glaciers descend to a very low elevation. The glaciers are mainly represented in the basins of the rivers of Achapara, Klich and Nakhari.

According to K. Podozerskiy (1911) there were 25 glaciers with the area of $16.6 \mathrm{~km}^{2}$ in the Klich River basin at the end of the 19th century. By the data of 1960 the number of the glaciers was 28 with the area of $9.5 \mathrm{~km}^{2}$. We should indicate that the distribution of the glaciers in the topographical map of 1960 and of K. Podozerskiy do not coincide with each other. The glaciers given in the Catalogue of K. Podozerskiy were not reflected in the data of 1960. It is related to the small glaciers or the snow spots, which have disappeared due to the intense retreat of the glaciers or they still are the snow spots (in the Achapara gorge and near the Klukhori Pass). By the data of 2014 the number of glaciers is 29 with the total area of $6.1 \mathrm{~km}^{2}$. It follows that after 1960 the total area of the glaciers has reduced by $35.6 \%$ and the number has increased by the 1 glacier.
There are mainly small cirque type glaciers in the Klich River basin. The glaciers located on the Khutia range are of eastern exposition; as for the glaciers located on the Klich range, their exposition is of western or north-western direction.

$20.0 \%$ of the total number and $15.2 \%$ of the total area of the glaciers of the Kodori River basin is a share of the glaciers of the Klich River basin. It is behind of the basins of the rivers of Chkhalta and Sakeni by the thickness of the ice sheet. In the Klich River basin the largest is the Klich glacier. Its length is $\sim 3.1 \mathrm{~km}$ and the area $-0.8 \mathrm{~km}^{2}$. The glacier starts from the Mount Klich and spreads to the northeastern direction. Its ice tongue ends at a height of $2450 \mathrm{~m}$ in the shape of a forehead; and in front of it there are well-expressed annual moraine hillocks, the height of which does not exceed $\sim 0.5-1.0 \mathrm{~m}$. These forms are created due to every year movement of the glaciers and fix the size of the glacier's retreating in time. The number of the arcwise hillocks is 15 and they end at the top of the ledge, but the annual moraines below are washed away and the bedrocks are outcropped. The moraines are located in parallel to each other and sometimes they cover each other [13].

There are three cirque type glaciers to the left of the Klich glacier. The glaciers exarate the bedrocks. Their bottom is quite inclined and the glaciers are not able to develop the moraines. The glaciers end nearly at a similar elevation.

Cirque type glaciers have retreated by 400-500 meters after the Fernau stage, on which indicate the well-developed lateral moraine hillocks in front of the glaciers and the lateral moraines which are extremely washed away. Among these three glaciers the right-hand glacier has very weakly developed moraines. This right-hand glacier was a Klich glacier's branch range during the Fernau stage. Its bottom is very inclined and does not allow the formation of moraines.

All early researchers mention the two glaciers to the right of the Klukhori Pass. Today there are powerful snow covers instead of them. Morphostructural character of the relief indicates that in the past (XIX century) here, for sure, should be the small glaciers of a cirque type, which are now melted and there are thick snow covers instead of them.

In the Ghvandra River basin there were 24 glaciers with the area of $7.2 \mathrm{~km}^{2}$ by K. Podozerskiy; by the data of D. Tabidze -20 glaciers with the area of $6.0 \mathrm{~km}^{2}$, and by the data of $1960-22$ glaciers with the area of $6.2 \mathrm{~km}^{2}$. By the data of 2014 there are 17 glaciers in this basin with a total area of $2.7 \mathrm{~km}^{2}$.

The Ghvandra River gorge has a shape of typical trough above the site of Mindora. Nevertheless, the Late Holocene stade moraines are weakly remained due to active erosion and gravitation processes [14].

Sakeni River basin is located between the ranges of the Greater Caucasus and Kodori. Its area is $\sim 233 \mathrm{~km}^{2}$. Glaciers are mainly located in the southern slope of the higher elevated Greater Caucasus and the western slope of the Kharikhra range. There are small glaciers in the northeastern slope of the Ghvaghva range. Sakeni River gorge is a second by the number and area of the glaciers among the Kodori 
River tributaries. $24.1 \%$ of the number and $24.0 \%$ of the area of all glaciers of the Kodori basin is a share of the Sakeni River basin.

By K. Podozerskiy (1911) there were 17 glaciers in the Sakeni River gorge with the area of $15.5 \mathrm{~km}^{2}$; by the data of 1960 there were 36 glaciers with the area of $19.1 \mathrm{~km}^{2}$, and by the data of 2014 there are 35 glaciers with the total area of $9.6 \mathrm{~km}^{2}$.

As for morphological types, here can be found all types of glaciers except of valley complex type.

Glaciers are mostly of commonly north exposition (N, NE, $\mathrm{NW}$ ). This is due to the abundance of glaciers on the western slopes of the Kharikhra range.

Sakeni glacier, which is located in the southern slope of the Greater Caucasus, is the largest by area in the Sakeni River basin. It is a valley type glacier and has the southeastern exposition. In 1911 the glacier area was $2.8 \mathrm{~km}^{2}$; In $1960-2.5$ $\mathrm{km}^{2}$ and by the data of 2014 its area is $2.0 \mathrm{~km}^{2}$ (Fig. 7).

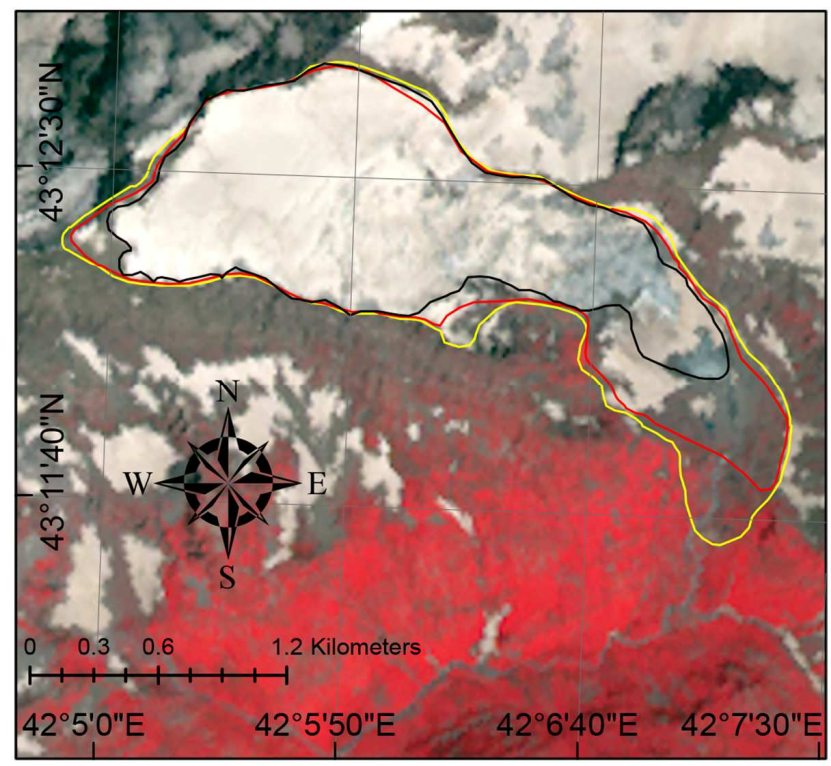

Fig. 7. The Retreat of Sakeni Glacier in 1911-1960-2014
Brakhma River basin is located on the north slope of the central section of the Kodori range. The range has a horizontal direction and is not high hypsometrically (Mount Khojali $3314 \mathrm{~m}$ ), which causes a lack of glaciers. There are 4 glaciers in this basin with the area of $0.4 \mathrm{~km}^{2}$. Three glaciers are of cirque type, and one - of cirque-valley. Glaciers are distinguished with their small sizes. Their expositions are of northern and northwestern direction. K. Podozerskiy did not mention the glaciers in this basin. But by the data of 1960 there were 4 glaciers with the total area of $1.2 \mathrm{~km}^{2}$ in this basin.

Amtkeli River basin. The Amtkeli River originates in the southwestern slope of the Chkhalta range. An old vast cirque of the northwestern direction is well represented in its headwaters. Today, there is one small cirque type glacier of the northwestern exposition. In 1960 its area was $0.08 \mathrm{~km}^{2}$, and by the 2014 data it is $0.07 \mathrm{~km}^{2}$.

\section{Conclusions}

The research revealed that increasing in number of glaciers in the years of 1911-1960 was caused by the degradation of glacial cover during their division (Fig 8). If we compare the data of the years of 1946-1960, we will see that in this period both the increase in area and number took place, which is very suspicious to us, because the increase in glacial cover is not recorded in other basins of the Great Caucasus in the mentioned years.

Data of 1946 is taken from the materials of D. Tabidze, who had conducted a great work to research the glaciers in the study region [12]. He studied the Kodori River basin glaciers in detail and gave us a new catalogue, which is mainly based on the 1:50,000 scale topographic maps compiled in 1952. It should be also specified that the glaciers are very poorly depicted on the mentioned maps. Maps are drawn based on the aeroimages of 1946. This may be caused the fact that D. Tabidze mapped the reduced glacial cover.

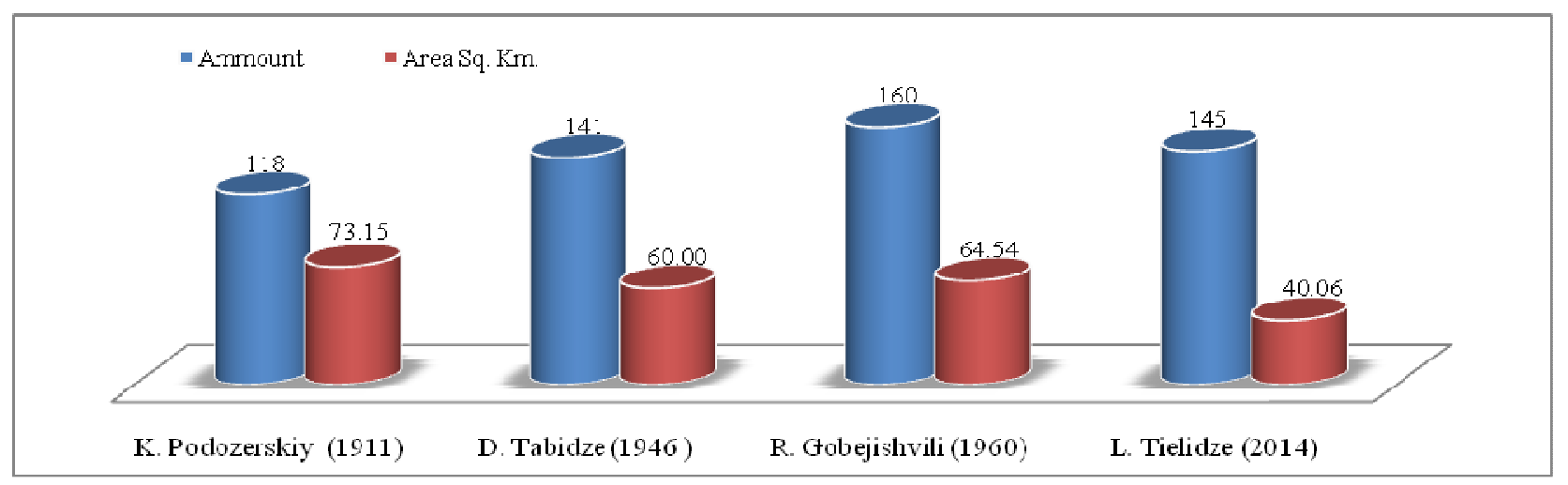

Fig. 8. Dynamics of the glaciers in the Kodori River basin in 1911-1946-1960-2014

Data of 1911-1960 well reflects the situation which was typical for evolution of glaciation in the Greater Caucasus till 1960-1980. In the years of 1960-1980 the area of the glaciers was reduced and their number was increased at the same time.
We can't say the same today, because as recent studies have shown, along with the reduction in area of the glaciers the decrease in number of them takes place during the last half a century. The same situation is in the Kodori River basin, when 
the area of the glaciers has reduced by $37.9 \%$ in $1960-2014$ $\left(24.5 \mathrm{~km}^{2}\right)$, while the number of glaciers has decreased by 15 (9.4\%) (Fig. 8). Overall in 1911-2014 the area of the glaciers has decreased by $45.2 \%\left(33.1 \mathrm{~km}^{2}\right)$ in the Kodori River Basin.

\section{Acknowledgements}

We are grateful to the Shota Rustaveli Georgian National Science Foundation for the financing our research.

\section{References}

[1] Kaltenborn B.P., Nellemann C., Vistnes I.I. (Eds). (2010). High mountain glaciers and climate change - Challenges to human livelihoods and adaptation. United Nations Environment Programme, GRID-Arendal, http://www.grida.no

[2] Tielidze L. G. (2014). Glaciers of Georgia, Monography, Publ. "Color" 254 p. Tbilisi. (in Georgian).

[3] Kotlyakov V.M., Dyakova A.M., Koryakin V.S., Kravtsova V.I., Osipova G.B., Varnakova G.M., Vinogradov V.N., Vinogradov O.N. and Zverkova N.M. (2010). Glaciers of the former Soviet Union. In: Williams, R.S. Jnr and Ferrigno, J.G., (eds.) Satellite image atlas of glaciers of the world - Glaciers of Asia: U.S. Geological Survey Professional Paper 1386-F-4 (doi:1386-F-4)

[4] Tielidze, L.G., Gadrani, L. and Kumladze, R. (2015) A One Century Record of Changes at Nenskra and Nakra River Basins Glaciers, Causasus Mountains, Georgia. Natural Science, 7, 151-157. http://dx.doi.org/10.4236/ns.2015.73017

[5] Gobejishvili R.G. (2011). Relief of Georgia, Monography, Publ. „Universali” 258 p. (in Georgian).

[6] Bayr K.J., D.K. Hall and W.M. Kovalick (1994). Observations on glaciers in the eastern Austrian Alps using satellite data. Int. J. Remote Sensing, 15(9), 1733-1752.
[7] Paul F. (2000). Evaluation of different methods for glacier mapping using Landsat TM. In Proceedings of EARSeL SIG Workshop, Land Ice and Snow, June 16-17, 2000, Dresden, Germany. Paris, European Association of Remote-Sensing Laboratories Special Interest Group Land Ice and Snow, 239-245.

[8] Paul F. (2002). Changes in glacier area in Tyrol, Austria, between 1969 and 1992 derived from Landsat TM and Austrian glacier inventory data. Int. J. Remote Sensing, 23(4), 787-799.

[9] Paul F., C. Huggel, A. Kaab, T. Kellenberger and Maisch M. (2002). Comparison of TM-derived glacier areas with higher resolution data sets. In Proceedings of EARSeL LISSIG Workshop, Observing our Cryosphere from Space, March 11-13, 2002, Bern, Switzerland. Paris, European Association of Remote-Sensing Laboratories Special Interest Group Land Ice and Snow, 15-21.

[10] Shahgedanova M., Nosenko G., Kutuzov S., Rototaeva O. and Khromova T. (2014). Deglaciation of the Caucasus Mountains, Russia/Georgia, in the 21 st century observed with ASTER satellite imagery and aerial photography The Cryosphere, 8 , 2367-2379, doi:10.5194/tc-8-2367-2014

[11] Podozerskiy K.I. (1911). Glaciers of the v Caucasus Mountain Range. “Zap. KORGO”, vol. 14, issue 1, (in Russian ).

[12] Tabidze D. (1965). Geomorphology of Kodori River basin. Thesis for a Phd's degree, 120 p. Tbilisi. (in Russian).

[13] Gobejishvili R.G. (1995). Present day glaciers of Georgia and evolution of glaciation in the mountains of Eurasia in late Pleistocene and Holocene. Thesis for a Doctor's degree, $320 \mathrm{p}$. Tbilisi. (in Georgian).

[14] Gobejishvili, R., N. Lomidze, and L. Tielidze (2011), Late Pleistocene (Wurmian) glaciations of the Caucasus, in Quaternary Glaciations: Extent and Chronology, edited by J. Ehlers, P. L. Gibbard, and P. D. Hughes, pp. 141-147, Elsevier, Amsterdam. DOI: 10.1016/B978-0-444-53447-7.00012-X 